\title{
The Implementation of Patient Safety by Nurses Based on Work Design
}

\author{
Sri Hananto Ponco Nugroho' ${ }^{1}$, Puguh Widiyanto ${ }^{2}$ \\ ${ }^{1}$ Correspondence Author: hanantoponco@ummgl.ac.id \\ ${ }^{1}$ Faculty of Health Science, Universitas Muhammadiyah Magelang, Indonesia \\ 2Faculty of Health Science, Universitas Muhammadiyah Magelang, Indonesia
}

\section{N D E X I N G}

Keywords:

Patient Safety;

Work Design;

Nurse.

Kata kunci:

Keselamatan pasien;

Desain kerja;

Perawat pelaksana. \begin{abstract}
A B S T R AC T
Patient safety incidents are increasing and can result in death. Hospitals are required to provide quality and safe service. Thus, making policies to improve the quality of patient safety based on evidence is very important. This study aimed to determine the relationship between work design and the implementation of patient safety by the nurses. The design of this research was a descriptive correlation with a crosssectional approach. The sampling technique used purposive sampling with a total sample of 56 nurses in the Inpatient Room of a hospital in Temanggung Regency. The data was collected through a work design questionnaire instrument and digital instrument/ calculators obtained through observation. Then, the data were analyzed by the chi-square test. The results showed that there was a significant relationship between work design and the implementation of patient safety by the nurses $(\mathrm{p}=$ 0.000 ). Nurses who had a good perception of work design were found to carry out patient safety well.
\end{abstract}

Insiden keselamatan pasien semakin meningkat dan dapat mengakibatkan kematian. Rumah sakit dituntut memberikan kualitas pelayanan yang bermutu dan aman sehingga sangat penting dalam pengambilan kebijakan untuk meningkatkan mutu pelaksanaan patient safety yang berdasarkan evidence based. Penelitian ini bertujuan untuk mengetahui hubungan desain kerja dengan pelaksanaan keselamatan pasien perawat pelaksana. Desain penelitian yang digunakan adalah korelasi deskriptif dengan pendekatan cross sectional. Teknik pengambilan sampel menggunakan purposive sampling dengan jumlah sampel sebanyak 56 perawat pelaksana di Ruang Rawat Inap sebuah rumah sakit di Kabupaten Temanggung. Pengumpulan data menggunakan instrumen kuesioner desain kerja dan instrument digital/kalkulator pelaksanaan keselamatan pasien dengan teknik observasi. Selanjutnya data yang ditemukan di analisis menggunaan uji chi square. Hasil penelitian menunjukkan ada hubungan bermakna antara desain kerja dengan pelaksanaan keselamatan pasien yang dilakukan perawat pelaksana $(p=0,000)$. Perawat yang memiliki persepsi desain kerja yang baik ditemukan melaksanakan keselamatan pasien dengan baik.

(C) 2020 JMMR. All rights reserved

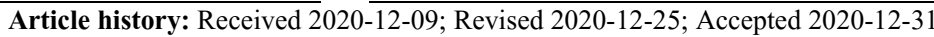

\section{INTRODUCTION}

One of the hospital obligations is to improve hospital service quality; one of which is safety service. The improvement in the safety service can provide a sense of security and comfort for patients. Hospitals are required to carry out patient safety goals according to the applicable regulations (Permenkes RI, 2018). This is an important point considering that the hospital is one of the strategic health facilities in accelerating the improvement of public health status (UU RI, 2009).

Data from several studies suggested that the increase in patient safety incidents resulted in death. However, some parties did not report actual patient safety incident data due to fear (Alves et al., 2019). More than 13 million patient safety incidents had been reported in 
England and Wales for over 10 years. In other words, there were more than 100,000 patient safety incident reports submitted every month (Hussain et al., 2019; Carson-Stevens et al., 2015). In the Toyama University Hospital Japan, 21,324 incidents related to patient safety were reported in 10 years Also, it was found $72.82 \%$ of the 31,333 reports of patient safety incidents occurred in the treatment room (Evans et al., 2019).

The six patient safety goals include identification of patients in an appropriate manner; the use of effective communication systems; attention to the administration of drugs that need to be aware of; accuracy in marking the location, procedure, and patient who perform surgery; minimize the risk of infection; and prevent fall risk events (Permenkes RI, 2017). Research in Yogyakarta showed that policies regarding the six patient safety goals had not been prepared and implemented properly (Sundoro et al., 2016). Syam \& Hastuti (2018) research also indicated that the compliance rate for safety implementation was still low. Other research related to patient safety also showed that the SBAR communication process was not optimal (Dewi et al., 2019). Research in Sukoharjo indicated that $41.4 \%$ of nurses did not wash their hands when taking care of the patients (Wulandari \& Sholikah, 2017). Research by Rahmawati et al (2020) in Blitar figured out that nurses showed low compliance in carrying out patient identification.

A preliminary survey carried out at the research location indicated that in 2019 the percentage of efforts to prevent the risk of injury/fall was $89 \%$ (standard 100\%), handwashing compliance was 79\% (standard $85 \%$ ), effective communication implementation was $61 \%$ (standard 100\%), patient identification compliance was $97 \%$ (standard $100 \%$ ), location and operation procedure errors were $0 \%$ (standard $0 \%$ ), and medication error was $6 \%$ (standard $0 \%$ ). However, according to the hospital, the results were not valid because continuous identification had not been carried out and easy-to-use instruments were not applied.

Work design variables will affect staff performance (Manik, 2017). Work design is a part of a manager's plan to implement duties and responsibilities (Suprihanto, 2018). Tasks are arranged according to the classification of each individual. A well-designed job will increase motivation so that it will improve performance (Anugrahini et al., 2010).

Based on the data above, it is very important to research the implementation of patient safety by nurses based on the work design. There are three main reasons why this research should be conducted. The first reason is that the assessment of the implementation of patient safety is not yet valid. The second reason is that the work design has never been assessed. The third reason is that the use of indicators for work planning, Skill Variety, Task Identity, Task Significance, Autonomy, and Feedback was not used in previous work design instruments. The fourth reason is that applicable digital instruments/calculators for the implementation of patient safety were not available in the previous studies. The fifth reason is related to the obligation of hospitals to carry out patient safety goals following applicable regulations so that they can provide quality service, a sense of security, and comfort for patients. Thus, it is very important to create policies that can improve the quality of patient safety implementation based on evidence. The purpose of this study was to analyze the relationship between work design and the implementation of patient safety by nurses in the inpatient room of a hospital in Temanggung Regency. 


\section{RESEARCH METHOD}

This research was a descriptive correlation study with a cross-sectional approach. The study was conducted in the inpatient room of a hospital in Temanggung Regency, Central Java from February to April 2020. The population was nurses who administered inpatient rooms. Samples were obtained through the purposive sampling technique with a total sample of 54 nurses. The data were collected through two kinds of instruments: work design questionnaire and digital instruments/calculators which were obtained through observation. Then, the data were analyzed using the chi-square test.

\section{RESULT AND DISCUSSION}

Data on the characteristics of respondents can be perceived in Table.1 below;

Table.1 Characteristics of Respondents

\begin{tabular}{lc}
\hline \multicolumn{1}{c}{ Variables } & Results \\
\hline Age & 33.52 \\
Mean & 6.99 \\
SD & $22-45$ \\
Min-max & \\
Length of Employment & 9.78 \\
Mean & 6.49 \\
SD & $1-23$ \\
Min-max & \\
Education, $\sum$ (\%) & $53(94.6)$ \\
Diploma III of Nursing & $3(5.4)$ \\
Bachelor of Nursing & \\
Gender, $\sum$ (\%) & $23(41.1)$ \\
Male & $33(58.9)$ \\
Female &
\end{tabular}

Source: Data Analyzed (2020)

It can be perceived in Table 1 that the average age of the respondents was 33.52 years and the average length of employment was 9.78 years. The majority of the educational background was Diploma III of Nursing (94.6\%) and the gender was dominated by the female $(58.9 \%)$.

Tabel.2 Work Design and the Implementation of Patient Safety

\begin{tabular}{lccc}
\hline \multicolumn{1}{c}{ Variables } & Category & Frequency & Percentage \\
\hline The Implementation of & Poor & 11 & 19.6 \\
Patient Safety & Good & 45 & 80.4 \\
Work Design & Poor & 14 & 25 \\
& Good & 42 & 75 \\
\hline
\end{tabular}

Source: Data Analyzed (2020)

Table. 2 showed that most of the respondents (75\%) had a good perception of the implementation of work design related to patient safety. Likewise, in the implementation of 
patient safety, it was found that most of the respondents $(80.4 \%)$ performed good implementation of patient safety.

Tabel.3 The Implementation of Patient Safety based on Work Design

\begin{tabular}{|c|c|c|c|c|c|c|c|}
\hline \multirow{3}{*}{$\begin{array}{c}\text { Work Design } \\
\text { Variables }\end{array}$} & \multicolumn{4}{|c|}{ The Implementation of Patient Safety } & \multirow{2}{*}{\multicolumn{2}{|c|}{ Total }} & \multirow{3}{*}{$\begin{array}{c}\mathrm{P} \\
\text { Value }\end{array}$} \\
\hline & \multicolumn{2}{|c|}{ Poor } & \multicolumn{2}{|c|}{ Good } & & & \\
\hline & $\mathbf{n}$ & $\%$ & $\mathrm{n}$ & $\%$ & $\mathbf{n}$ & $\%$ & \\
\hline Poor & 8 & 57.1 & 6 & 42.9 & 14 & 100 & 0.000 \\
\hline Good & 3 & 7.1 & 39 & 92.9 & 42 & 100 & \\
\hline Total & 11 & 19.6 & 45 & 80.4 & 56 & 100 & \\
\hline
\end{tabular}

Source: Data Analyzed (2020)

Based on Table.3, nurses (92.9\%) who had a good perception of work design mostly carryied out good patient safety practices. On the other hand, nurses $(57.1 \%)$ who had a poor perception of work design mostly carryied out poor patient safety practices. The results of the chi-square analysis concluded that there was a significant relationship between work design and the implementation of patient safety $(p=0.000, p<0.05)$.

The results of the analysis showed that $85.7 \%$ of the nurses carried out patient safety procedures well. Based on the observations, most nurses carryied out six patient safety goals which included procedures for properly identifying patients; use effective communication systems; give attention to the administration of drugs which need to be aware of; accuracy in marking the location, procedure, and patient performing surgery; minimize the risk of infection, and prevent the risk of falling. Several factors affecting the implementation of patient safety are age, length of employment, level of education, and motivation. These factors affect the implementation of good patient safety (Nugroho \& Sujianto, 2017).

The average age of the respondents was 33 years so that it could affect the implementation of good patient safety. This statement is in line with the results of Setyani et al (2017) research which stated that nurses aged more than 35 years tended to obey patient safety goals. Another study conducted by Handayani et al (2018) concluded that there was a relationship between age and nurse performance. Nurses aged less than 35 years would have good performance compared to those aged more than 35 years. This is because the nurses has good physical activities. As they get older, their work productivity will also decrease. This is following the opinion of Robbins \& Coulter (2015) which stated that an increase in age caused a decrease in physical activity and automatically resulted in work productivity decrease.

Aaccording to the researchers' analysis, another cause was due to the length of employment. The respondents of this study had an average length of employment of 9.78 years. The length of employment provides a good experience for nurses, especially in providing optimal nursing services to patients including patient safety practices. This is confirmed by the results of research by Setyani et al (2017), they concluded that there was a relationship between the length of employment and the implementation of patient safety goals. Nurses with a service of more than 5 years tended to be better at implementing patient safety goals.

Research by Miladiyah et al (2015) also strengthened the results of this study which mentioned that nurses with a length of employment under 10 years yielded good 
performance. Therefore, the length of employment can provide an overview of work experience and productivity, so that it will improve one's performance. The head of the room can make various innovations to maintain or improve the performance of nurses with a diverse length of employment. Thus, regardless of the length of employment, they will be able to carry out good performance, especially in providing nursing services according to patient safety standards.

Furthermore, good implementation of patient safety was also affected by nurses' level of education who were mostly in Diploma III of Nursing. This is following the research of Fadriyanti \& Suryarinilsih (2018) which revealed that there was a relationship between the level of education and the implementation of patient safety goals. Nurses with a minimum education of Diploma III would perform good implementation of patient safety goals. This shows that the higher the level of education, the greater the percentage of good implementation of patient safety. Higher education levels generally have broader knowledge and good problem analysis mastery so that they are more able to accept positions and responsibilities as well as applying their knowledge in work. Knowledge is related to the level of education (Nur et al., 2019).

Psychological factors including motivation also had a good impact on the implementation of patient safety. The average age of the respondents was less than 35 years, which meant they had better motivation in carrying out various tasks and providing good nursing services to the patients. Motivational factors are very important in care management and nursing care because they can influence good behavior towards the services provided to patients. The motivation was very important to realize activities in providing care to patients (Bakri, 2017). This was also in line with Miladiyah et al (2015) research which stated that nurses aged 20 to 35 years had a good motivation that affected the performance of nurses twenty-six higher. Other studies also proved similar results. Wulandari et al (2019) stated that there was a significant relationship between nurse motivation and patient safety culture; the better the nurse's motivation, the better the nurse's performance in implementing patient safety culture. Therefore, the head of the room needs to motivate according to the needs, so that the nurses can carry out service activities based on patient safety principles.

good implementation of patient safety. However, $14.3 \%$ of the respondents still did not perform the good implementation of patient safety, for example, 1) before taking an action, nurses had to conduct patient identification; however nurses did not check the patient's identity in the bracelet and did not use open-ended questions; 2) SBAR (Situation, Background, Assessment, Recommendation) communication system which needed to be used optimally in all service reporting communication systems; 3) the implementation of handwashing according to the standard needed to improve; 4) no regular and scheduled observation in patients at risk of falling. In short, it is necessary to increase the implementation of patient safety for all nurses in the inpatient room.

Real efforts must be performed by the head of the room or hospital leadership to improve the implementation of patient safety for all nurses so that $100 \%$ of nurses can achieve the same quality of service. Patient safety must always be improved to prevent patient harm (Graban, 2016). The services provided to patients, especially those related to patient safety, will have a direct impact on patient satisfaction. Good patient safety implementation by nurses will automatically increase patient satisfaction. This is in line with the results of the 
study by Widiasari et al (2019) which concluded that there was a relationship between the application of patient safety and patient satisfaction.

The results of the analysis showed that most of the nurse administrators or $75 \%$ had a good perception of the work design. This means that the work design implementation carried out by the head of the room is acceptable and can be carried out properly by the majority of the nursing staff in each room or ward. Work design is one of the driving factors for organizational productivity (Purnaya, 2016). Work design will focus on designing or planning activities fundamentally to maximize performance (Rismawati \& Mattalata, 2018). Therefore, in implementing the work design it is necessary to set goals and strategies applied by the head of the room, which focuses on performance activities.

According to Hackman and Oldham, as cited by Robbins \& Coulter (2015), in the work design indicators, there was a diversity of skills, job identity, job meaning, autonomy, and feedback. Based on the researchers' observations, the element of autonomy is very important in the success of work design. This is in line with research by Pujoraharjo \& Diah (2015) which confirmed that autonomy was the most important factor as it achieved the highest percentage of agreed answers. The autonomy offered to staff is in terms of work planning activities, freedom in work, and decision making. Nursing staff who are given autonomy will tend to be responsible because they are trusted according to their abilities.

Based on the analysis in this study, it is concluded that there is a relationship between work design and the implementation of patient safety. In general, work design will carry out activities following the planned assignments, technical and job descriptions to be carried out, and how the implementation of these activities will be related to other activities in the organization so that all activities are carried out based on plans prepared in the work design (Purnaya, 2016). The implementation of a good work design will certainly increase supervision by the head of the room towards nurses in the management of patient safety implementation. Thus, the quality of service provided by nurses to patients will be in accordance with the principles of patient safety. This is confirmed by the results of research by Rahmawati et al (2020) which stated that one of the factors causing the low patient identification was the low level of supervision from the head of the room.

The implementation of patient safety is part of the performance element of staff duties management. Thus, patient safety management will be related to staff performance. The results of Pujoraharjo \& Diah (2015)' research, as well as Manik (2017) research, found that work design had a positive effect on staff performance. Research by Khaerunnisa et al (2015) stated that there was a relationship between work design and nurse performance. Staffs that getting better at perceiving work designs will increase their motivation to behave innovatively (Khasanah \& Himam, 2018). This means that the better the work design carried out by the head of the room, the better the implementation of patient safety by the nurse, which will also have a good impact on staff performance in general.

\section{CONCLUSION}

According to the research objectives, it can be concluded that there is a significant relationship between work design and the implementation of patient safety in the inpatient room of a hospital in Temanggung Regency. The hospital must support the improvement of the implementation of patient safety through the work design by the head of the room. Therefore, it is necessary to prepare a Standard Operating Procedure related to the 
implementation of work design and increase the competence of the head of the room in the implementation of work design. The head of the room needs to improve the quality of the work design implementation so that the implementation of patient safety is carried out properly by all nurses. The results of this study can be used as initial data for the development of further research on work design or implementation of patient safety so that it can improve the implementation of patient safety for nurses in service.

\section{ACKNOWLEDGMENT}

Thanks to LP3M Universitas Muhammadiyah Magelang for the financial assistance provided in the Penelitian Revitaliasi Visi Institusi (PRVI) contract number 004/Kontrak/PRVI-PA/2020 and all respondents who helped carry out this research.

\section{REFERENCE}

Alves, de F. T., Michelle, de Carvalho, D. S., \& de Albuquerque, G. S. C. (2019). Barriers to patient safety incident reporting by Brazilian health professionals: an integrative review. Revista Ciência Eु Saúde Coletiva, 24(8), 2895-2908. 10.1590/1413. 81232018248.23912017

Anugrahini, C., Sahar, J., \& Mustikasari. (2010). Kepatuhan Perawat Menerapkan Pedoman Patient Safety Bedasarakan Faktor Individu dan Organisasi. Jurnal Keperawatan Indonesia, 13(3), 139-144. https://doi.org/10.7454/jki.v13i3.244

Bakri, M. H. (2017). Manajemen Keperawatan Konsep dan Aplikasi dalam Praktik Keperawatan Profesional. Yogyakarta: Pustaka Baru Press.

Carson-Stevens, A., Hibbert, P., Avery, A., Butlin, A., Carter, B., Cooper, A., Evans, H. P., Gibson, R., Luff, D., Makeham, M., McEnhill, P., Panesar, S. S., Parry, G., Rees, P., Shiels, E., Sheikh, A., Ward, H. O., Williams, H., Wood, F., ... Edwards, A. (2015). A cross-sectional mixed methods study protocol to generate learning from patient safety incidents reported from general practice. BMJ Open, 5(12), e009079. https://doi.org/10.1136/bmjopen-2015-009079

Dewi, R., Rezkiki, F., \& Lazdia, W. (2019). Studi Fenomenology Pelaksanaan Handover Dengan Komunikasi SBAR. 4(2), 350-358.

Evans, H. P., Anastasiou, A., Edwards, A., Hibbert, P., Makeham, M., Luz, S., Sheikh, A., Donaldson, L., \& Carson-Stevens, A. (2019). Automated classification of primary care patient safety incident report content and severity using supervised machine learning (ML) approaches. Health Informatics Journal, 1460458219833102. https://doi.org/10.1177/1460458219833102

Fadriyanti, Y., \& Suryarinilsih, Y. (2018). Hubungan Jam Kerja dan Karakteristik Perawat Pelaksana dengan Penerapan Sasaran Keselamatan Pasien pada Rumah Sakit di Kota Padang. Menara Ilmu, 12(6).

Graban, M. (2016). Lean Hospitals: Improving Quality, Patient Safety, and Employee Engagement. CRC press.

Handayani, S., Fannya, P., \& Nazofah, P. (2018). Faktor yang Berhubungan dengan Kinerja Tenaga Kesehatan di Rawat Inap RSUD Batusangkar. Jurnal Endurance, 3(3), 440-448. https://doi.org/10.22216/jen.v3i3.3005

Hussain, F., Cooper, A., Carson-Stevens, A., Donaldson, L., Hibbert, P., Hughes, T., \& 
Edwards, A. (2019). Diagnostic error in the emergency department: learning from national patient safety incident report analysis. BMC Emergency Medicine, 19(1), 1-9. https://doi.org/10.1186/s12873-019-0289-3

Khaerunnisa., Sukri., Nurhayani. (2015). Hubungan Faktor Organisasi Dengan Kinerja Perawat Ruang Rawat Inap Di Rsud Kabupaten Sinjai. Fkm Unhas, 1-11.

Khasanah, I. F. N., \& Himam, F. (2018). Kepemimpinan Transformasional Kepribadian Proaktif dan Desain Kerja sebagai Prediktor Perilaku Kerja Inovatif. Gadjah Mada Journal of Psychology (Gamajop), 4(2), 143-157.

Manik, E. (2017). Pengaruh Budaya Organisasi, Desain Kerja Dan Kualitas Supervisi Terhadap Kinerja Pegawai. Majalah Bisnis Dan IPTEK, 10(2), 150-159.

Miladiyah, N., Mustikasari, M., \& Gayatri, D. (2015). Hubungan Motivasi dan Komitmen Organisasi dengan Kinerja Perawat dalam Pelaksanaan Dokumentasi Asuhan Keperawatan. Jurnal Keperawatan Indonesia, 18(1), 9-16. https://doi.org/10.7454/jki.v18i1.392

Nugroho, S. H. P., \& Sujianto, U. (2017). Supervisi Kepala Ruang Model Proctor untuk Meningkatkan Pelaksanaan Keselamatan Pasien. Jurnal Keperawatan Indonesia, 20(1), 56-64.

Nur, R., Salmawati, L., Nutfa, S., Krisnasari, S., Rau, J., Radiah, \& Patui, N. S. (2019). Knowledge, Attitudes of Nurses with Implementation of Patient Safety in Undata General Hospital of Central Sulawesi Province. Indian Journal of Public Health Research E Development, 10(12), 1956-1960. http://eresources.perpusnas.go.id:2048/login?url=http://search.ebscohost.com/login.aspx?dire $\mathrm{ct}=$ true $\& \mathrm{db}=\mathrm{edsijc} \& A \mathrm{~N}=$ diva.ijphrd.10.12.391\& $\&$ site=eds-live

Permenkes RI. (2017). Peraturan Menteri Kesehatan Republik Indonesia Nomor 11 Tahun 2017 tentang Keselamatan Pasien.

Permenkes RI. (2018). Peraturan Menteri Kesehatan RI nomor 4 Tahun 2018 Tentang Kewajiban Rumah Sakit dan kewajiban Paisen.

Pujoraharjo, P., \& Diah, Y. M. (2015). Pengaruh Kompetensi dan Desain Kerja terhadap Kinerja Karyawan (Studi Kasus di Departemen Gigi dan Mulut Rsup Dr. Mohammad Hoesin Palembang). Jurnal Manajemen Dan Bisnis Sriwijaya, 13(4), 507-524.

Purnaya, I. G. K. (2016). Manajemen Sumber Daya Manusia. Penerbit Andi.

Rahmawati, T. W., Sari, D. R., Ratri, D. R., \& Hasyim, M. (2020). Patient Identification in Wards: What Influences Nurses' Complicance? JMMR (Jurnal Medicoeticolegal Dan Manajemen Rumah Sakit), 9(2), 110-120.

Rismawati, \& Mattalata. (2018). Evaluasi Kinerja: Penilaian Kinerja Atas Dasar Prestasi Kerja Berorientasi Kedepan (Vol. 1). Celebes Media Perkasa.

Robbins, S., \& Coulter, M. (2015). Management. Pearson Education. https://books.google.co.id/books?id=S8OgBwAAQBAJ

Setyani, M. D., Zuhrotunida, Z., \& Syahridal, S. (2017). Implementasi Sasaran Keselamatan Pasien Di Ruang Rawat Inap RSU Kabupaten Tangerang. Jurnal JKFT, 1(2), 59-69.

Sundoro, T., Rosa, E. M., \& Risdiana, I. (2016). Evaluasi Pelaksanaan Sasaran Keselamatan Pasien Sesuai Akreditasi Rumah Sakit Versi 2012 di Rumah Sakit Khusus Ibu dan Anak PKU Muhammadiyah Kotagede Yogyakarta. 5(1), 40-48. https://doi.org/10.18196/jmmr.5105.Evaluasi 
Suprihanto, J. (2018). Manajemen. Gadjah Mada University Press.

Syam, N. S., \& Hastuti, S. K. W. (2018). Relationship between knowledge and attitude with implementation of patient safety targets in RSUD Yogyakarta. JMMR (Jurnal Medicoeticolegal Dan Manajemen Rumah Sakit), 7(3), 205-211.

UU RI. (2009). Undang-Undang Republik Indonesia Nomor 44 Tahun 2009 Tentang Rumah Sakit.

Widiasari, Handayani, H., \& Novieastari, E. (2019). Kepuasan Pasien Terhadap Penerapan Keselamatan Pasien Di Rumah Sakit. Jurnal Keperawatan Indonesia, 22(Januari), 43-52. https://doi.org/10.7454/jki.v22i1.615

Wulandari, M. R., Yulia, S., \& Triwijayanti, R. (2019). Peningkatan Budaya Keselamatan Pasien Melalui Peningkatan Motivasi Perawat dan Optimalisasi Peran Kepala Ruang. Jurnal Kepemimpinan Dan Manajemen Keperawatan, 2(2), 58-66.

Wulandari, R., \& Sholikah, S. (2017). Pengetahuan dan Penerapan Five Moment Cuci Tangan Perawat Di RSUD Sukoharjo. XV(1). 